\title{
THEORETICAL ASPECTS OF PUBLIC ADMINISTRATION ELECTRONIC SERVICES
}

\author{
Jozef Andraško \\ Comenius University in Bratislava, Faculty of Law
}

\begin{abstract}
The author deals with the issue of public administration electronic services from the theoretical perspective. In particular, author is analysing all elements of the term in question. Furthermore, the author focuses on different types of categorization of public administration electronic services. Moreover, author is dealing with the definition of the term in question from the perspective of Slovak legal order.
\end{abstract}

Key words: public service, electronic service, eGovernment, public administration electronic service

\section{INTRODUCTION}

The targeted and systematic introduction of information and communication technologies (hereinafter referred to as the "ICT") into all relevant areas of social, political and economic life also influenced the public administration. The process of public administration informatization resulted in the creation of the concept called eGovernment. Such a concept can be described as an electronic form of public administration exercise in the application of ICT in the public administration processes.

There are many definitions of the term eGovernment in literature and legal documents on international and national level. ${ }^{1}$ Most of definitions approach the eGovernment as introduction of ICT into public administration where public services and information can be provided online through the Internet. However, these definitions often avoid the description of electronic services that are provided by public authorities. Furthermore, it is possible to find opinions in favour of perception of public administration electronic services as electronic services provided within the e-commerce. The concept of e-Government has specific features that cannot be found in the e-commerce and vice versa. Therefore, it is necessary to focus on all elements of the term in question, especially from the perspective of administrative law. ${ }^{2}$

\section{PUBLIC ADMINISTRATION ELECTRONIC SERVICE - DEFINITION}

In order to understand the term public administration electronic service, all elements of the term in question have to be analysed separately. Firstly, we will focus on the term service. Secondly, we

1 More on the issue of the eGovernment definition in: HEEKS, R. Implementing and Managing eGovernment: an International Text, p. 1. See also: PRINS, J.E.J. E-Government and Its Implications for Administrative Law: Regulatory Initiatives in France, Germany, Norway and the United States, p. 7.

2 More on the issue of the eGovernment in the Slovak Republic see: SOPÚCHOVÁ, S. Predpoklady fungovania egovernmentu v Slovenskej republike. In QUAERE 2015, p. 659-668. 
will analyse the term public service. Last but not least, we will focus on the term electronic service. Subsequently, the definition of public administration electronic service will be formulated and analysed.

\section{Service}

Kotler and Keller define the service as "any act or performance one party can offer to another that is essentially intangible and does not result in the ownership of anything. Its production may or may not be tied to a physical product."3 Authors of literature consider as characteristic features of service intangibility ${ }^{4}$, inseparability and variability. ${ }^{5}$ Service is intangible to the effect that it deals with certain act, in particular performance and not as a product in physical form which can be touched. Service inseparability means that the moment of providing and using of most services is the same. Quality of service is connected with its providing, mostly by interaction between consumers and service provider. Service variability means that services of one service provider distinguish from services of another service provider. Furthermore, services can change in the time.

Kotler and Keller add another characteristic element of the term service, in particular perishability. Such an element deals with the fact that services opposed to goods cannot be stored what means that the service has to be available on request. ${ }^{6}$

\section{Public service}

In literature occur different perspectives on the term public service. ${ }^{7}$ Besides general definitions of the term in question it can be found also the definition of the term public service from the economic as well as from the legal point of view.

Lindgren and Jansson within comparison of public services with services offered by private sector refer to three main differences. Firstly, in the case of public service, public character is evident because public institutions' main task is to serve to the public in the way that in in compliance with public interest. Secondly, public organizations as public service providers are mostly in monopoly position because the list of public services is limited to only one provider and citizens have no other choice (e.g. welfare services). Furthermore, Lindgren and Jansson note that in the case of public services, the entity that is using specific public service cannot be perceived as the customer but rather as citizen that has a right to use service and such a right is protected by law. ${ }^{8}$

3 KOTLER, P. - KELLER, K.L. Marketing Management, p. 356.

4 Scupola challenges the views of the authors that the service must have an intangible character. He states that for example, information, data and knowledge services (so-called information services) may be provided in such a way that data, information and knowledge are recorded on a physical medium and may be provided as a commodity. See: SCUPOLA, A. et al. E-Services: Characteristics, Scope and Conceptual Strengths. In International Journal of E-Services and Mobile Applications, p. 2.

5 PARASURAMAN, A. et al. A Conceptual Model of Service Quality and Its Implications for Future Research. In Journal of Marketing, p. 41-50. ZEITHAML, V. A et al. Delivering Quality Service. Balancing Customer Perceptions and Expectations.

6 KOTLER, P. - KELLER, K.L. Marketing Management, p. 361.

7 The synonym of the term public service is the public administration service.

8 LINDGREN, I. - JANSSON, G. Electronic services in the public sector: A conceptual framework. In Government Information Quarterly, p. 163-172. 
According to Sauter are public services considered as services that are provided:

- to public and/or in public interest,

- in unified or regulated manner,

- by entities that are in public possession, ${ }^{9}$

Ochrana defines public service as "service which purpose is to satisfy public needs while creator, organizer or regulator of provided service is public administration institution. ${ }^{.10}$ Furthermore, Ochrana notes that as characteristic attributes of public service can be considered:

- purpose criterion of service provision is public interest and from this reason is its provision financed from public funds,

- continual character, from time perspective

- universal character, from the perspective of scope of service provision. ${ }^{11}$

From economical point of view, we could consider public services as public estate whose consumer is the public. However, according to Peková et. al. is necessary in the case of public service to emphasize that such a service can be characterized by inseparability of production and consumption with direct influence on user of service. Furthermore, public service can be characterized by impossibility of public service ownership what means that user has only right to use public service in question. ${ }^{12}$

From legal point of view, it is necessary to distinguish between public service as service relation and public service as specific service provided by public administration. ${ }^{13}$ In connection with aforementioned, Pomahač and Vidláková define public service as being in service (civil service) and public service as useful public activity (public service). ${ }^{14}$

Škrobák distinguishes between public services in narrow sense and broad sense from the perspective of public administration activity. Public service in narrow sense can be defined as "provision of specific real service to administrated persons what causes immediate satisfaction of certain needs of persons in question." ${ }^{15}$ In the case of public services in broad sense, we can consider service in the field of administrative or organizational executions (e.g. administrative acts or other executions that are the result of certain administrative procedure).$^{16}$

Public services can also be considered from organizational point of view where administering public administration entity that provides public services will be observed. ${ }^{17}$ In this respect, Škrobák states that public services can be provided:

9 Sauter further states that the last aspect of public service is no longer preferred in modern social states. See SAUTER, W. Public Services in EU Law, p. 11.

10 OCHRANA, F. Veřejné služby - problém vymezení pojmu a standardizace. In Standardizace veřejných služeb jako předpoklad efektivnosti rozvoje region, p. 16.

11 Ochrana later modifies the definition of public services. He states that the public service is: "such a kind of service to which the consumer (the consumer) is the public as a social entity. Public services are produced, secured or regulated by public authorities."

12 PEKOVÁ, J. et al. Veřejný sektor - řízení a financování, p. 29.

13 Čebišová distinguishes between four different alternative concepts of public service. Firstly, she defines public service as a role, a public service mission - a service in the public which becomes the principle and conceptual feature of public administration. Another alternative is the understanding of public service as an object, the content of public administration activities. The term public service also refers to certain authorities or sections of the public administration. Finally, she understands the public service as a sign of a public servant and his legal status. See ČEBIŠOVÁ, T. Veřejná služba na prahu 21. století. In Acta Universitas Carolinae, p. 9-39.

14 POMAHAČ, R. - VIDLÁKOVÁ, O. Veřejná správa, p. 71, p. 208.

15 ŠKROBÁK, J. In VRABKO, M. et al. Správne právo hmotné. Všeobecná čast', p. 41.

16 See SKULOVÁ, S. Princípy dobré správy jako součást modernizace veřejné správy. In Právnik, p. 553-585.

17 More information on issue of administering public administration entities see ŠKROBÁK, J. In VRABKO, M. et al. Správne právo hmotné. Všeobecná čast', p. 11-23. 
- „directly by the state or by other public law corporation through its mechanism,

- the state or other public law corporation will establish separate public administration entity which ensures the provision of public services on its own,

- public administration entity secures the provision of public services through natural persons and legal entities of public interest. "18

Škrobák also points out that in the case of public services provision, the principle on non-discrimination will be applied. The principle of non-discrimination means that persons cannot be baselessly favoured and decision making regarding provision of specific service has to be continual. ${ }^{19}$

In the light of aforementioned, it is obvious that perspective on the term public service is different depending on the fact in which field the term is used.

\section{Electronic service}

There are several definitions of the term electronic service in literature and documents on the international and national level. Some definitions focus on provision of service as such and infrastructure of service provision. Other definitions focus on the process of service creation and service provision. ${ }^{20}$

From the perspective of service provision and its infrastructure Javalgi et al. define electronic service as service that is provided by electronic means. ${ }^{21}$

Boyer a et al. define electronic services as "interactive services that are provided on the Internet by using modern telecommunication, information and multimedia technologies."22

The methodical guideline for the use of professional terms in the field of society informatization defines the term electronic service as "the service provided in electronic form through ICT."23

Scupola defined electronic services from the perspective of process of electronic service creation and provision as "services that are created and provided and/or used via ICT as systems based on the Internet and mobile solutions." ${ }^{\text {24 }}$

In connection with electronic services categorization, Hofacker defines following three categories:

a) electronic services as a complement to services and goods in the physical world (e.g. online reservation of seat in an aircraft),

b) electronic services as a substitute for services provided in physical world (e.g. electronic auction),

c) new electronic services provided only online (e.g. online search through search engines). ${ }^{25}$

18 ŠKROBÁK, J. In VRABKO, M. et al. Správne právo hmotné. Všeobecná čast p. 43-44.

19 Ibid., p. 42.

20 HOFACKER, C.F. et al. E-Services: A Synthesis and Research Agenda. In Journal of Value Chain Management, p. 13-44.

21 JAVALGI, R.G. et al. The Export of E-Services in the Age of Technology Transformation: Challenges and Implications for International Service Providers. In Journal of Services Marketing, p. 560-573.

22 BOYER, K. et al. E-services: operating strategy - a case study and a method for analyzing operational benefits. In Journal of Operations Management, p. 175.

23 MINISTERSTVO FINANCIÍ SLOVENSKEJ REPUBLIKY. Metodický pokyn na použitie odborných výrazov pre oblast informatizácie spoločnosti, p. 15.

24 SCUPOLA, A. et al. E-Services: Characteristics, Scope and Conceptual Strengths. In International Journal of E-Services and Mobile Applications, p. 6.

25 HOFACKER, C. F. et al. E-Services: A Synthesis and Research Agenda. In Journal of Value Chain Management, p. 13-44. 
In the light of aforementioned definitions, we could consider as the main features of electronic services:

- provision through ICT (mainly the Internet)

- direct or indirect use through ICT (mainly the Internet)

- possibility of charging by provider,

- principle of self-service - physical interaction between user and provider is not required. ${ }^{26}$

Regardless of different definitions and characteristics of electronic services, electronic services can be considered as services that are provided through ICT, however at the same time, procedures (within the organization that provides the service) that are intended to its provision have to be took into account.

\section{Public administration electronic services}

On the basis of aforementioned conceptual features of the term public administration electronic services we cannot satisfy with the definition of public administration services as public services that are provided through ICT (mainly the Internet). ${ }^{27}$

It is necessary to bear in our mind that provision of public administration electronic services is not always connected with specific output as in the case of e.g. providing primary education or treating the patient. In this respect, public administration electronic services only secure mediation of particular service through ICT (mainly the Internet).

When defining public administration electronic service, it is also necessary to take into account the position of service user. Such a user cannot be identified with the customer in the private sector. In this respect, user of public administration electronic services is mainly citizen that has a right to use specific public service, while principle of non-discrimination is applied. ${ }^{28}$

With respect to entities that provide public administration electronic services, they are mostly in monopoly position as in the case of public services provided in physical world. The citizen has no option to choose the provider of specific public administration electronic service. Furthermore, we could generally say that providers of these services are administering public administration entities. $^{29}$

For purposes of this paper we can define public administration electronic services as electronic form of communication between natural persons, entrepreneurs, legal entities on the one side and public administration on the other side within use of public services through ICT (mainly the Internet).

26 ŠPAČEK, D. eGovernment - cíle, trendy a př́stupy k jeho hodnocení, p. 4-5.

27 In literature, it is possible to find also terms like eGovernment service, electronic public service, public online service, digital electronic service, and so on. These terms can be considered as synonymous with the term public administration electronic services.

28 In addition to citizens (legal status of natural persons) also natural persons entrepreneurs and legal entities can use public administration electronic services.

29 In the case of some public administration electronic services, e.g. eHealth services, it is possible to provide these services in the public sector as well as in the private sector. Examples of eHealth services are online clinical services (such as consulting with a doctor) and online health information (e.g. helping people take care of their health). 


\section{CATEGORIZATION OF PUBLIC ADMINISTRATION ELECTRONIC SERVICES}

There are two types of categorization. The first categorization of public administration electronic services is based on the criterion of the interaction level between entities which are involved in the process of using and provision of these services. In order to define specific types of public administration electronic services in accordance with aforementioned criterion it is necessary to focus on eGovernment development models.

United nations (UN) defined eGovernment development models in 5 phases. In the first phase, public administration gets on the Internet through creation of official website. In the second phase, public administration is increasing amount of information available on the official websites (user can find e.g. legal acts or can access the database). The third phase is considered as interactive phase where user is allowed to download form, contact public administration bodies through the official e-mail. Online services become more interactive in the third phase. The fourth phase is transaction phase where user can perform transactions (e.g. payment of fees, apply for new identification card of duplicate of birth certificate). Public administration electronic services can be used 24/7. The last phase is based on the full integration of electronic services within whole public administration. This phase involves engaging society in public affairs by creating various web forums or innovative consulting applications. ${ }^{30}$

Authors of literature ${ }^{31}$ created various eGovernment development models. One of the first model was created by Layne a Lee (2001) where 4 phases were defined, in particular catalogue phase, transaction phase, phase of vertical integration and phase of horizontal integration. ${ }^{32}$ Another model was created by Silcock (2001) and was based on 6 phases, in particular phase of online publication of information, phase of official mutual transaction, phase of multipurpose portal, phase of adjustment of portal, phase of collecting common services and phase of full integration. ${ }^{33}$ Zourdis and Thaens (2003) defined besides information phase, interaction phase, transactional phase also the last phase in which the internal structure of the public administration is transformed. ${ }^{34}$

Regardless of differences in the eGovernment development models outlined above, these models also have common features. These features could be summed up for the purposes of this paper in 3 phases of eGovernment development model, in particular the informative phase, the interaction phase and the transactional phase.

In connection with aforementioned eGovernment development models, its structure as well as levels of interaction between entities that are involved in this structure, we could divide public administration electronic services to the following categories:

a) information public administration electronic services,

30 OSN: World Public Sector Report 2003. E-Government at the crossroads, p. 139. Available at: https://publicadministration.un.org/publications/content/PDFs/E-Library\%20Archives/World\%20Public\%20Sector\%20Report\%20series/World\%20Public\%20Sector\%20Report.2003.pdf.

31 More information about other analyses of eGovernment development models see CHAIKHI, L. et al. E-Government Maturity Models: A Comparative Studies. In International Journal of Software Engineering\&Applications, p. 71-91.

32 See LAYNE, K. - LEE, J. Developing fully functional E-government: A four stage model. In Government Information Quarterly, p. 122-136.

33 See SILCOCK, R. What is e-government? In Parliamentary Affairs, p. 88-101.

34 ZOURIDIS, S. - THAENS, M. E-Government: Towards a Public Administration Approach. In Asian Journal of Public Administration, p. 161. 
b) communication public administration electronic services,

c) transaction public administration electronic services.

Ad a) Public administration bodies as providers of public administration electronic services provide information about services through their official websites. The essence of services in question is publishing information online. Users, in particular citizens and entrepreneurs have access to information mostly anonymously what means that direct interaction is absent.

Ad b) Communication public administration electronic services also known as interactive public administration electronic services include beside information public administration electronic services also possibility to access the database of public administration bodies and searching information in such a database. Entities (e.g. citizens and public administration bodies) are interacting within these services (e.g. sending emails, requests, forms, etc.). Interactive public administration electronic services can be one-sided and two-side interactive services. In the case of one-side interactive services users can download the form, however it is necessary to send it physically (e.g. by post). Two-sided interactive services are services where users can download the form and subsequently it can be electronically sent to provider of the public administration electronic service. In the case of interactive services, particularly two-side interactive services, the service provider has to be sure who is he communicating with.

Ad c) Transaction public administration electronic services represent the highest level. These services include both information and communication public administration electronic services and moreover users can make various online transactions with the service provider. An inescapable condition for providing of such services is the ability to access services 24/7. For this reason, it is necessary for the provider of these services to create conditions within the back-office internal procedures and the privacy and security conditions. The provider of transactional public administration electronic services has to be sure who is he communicating with, what requires the explicit identification of the entities. ${ }^{35}$

The second categorization of public administration electronic service is based on the concept that public administration electronic services are public service that are provided through ICT, mainly via the Internet. It is necessary to point out that many public administration electronic services only mediate the provision of a specific public service in the physical world, while others are a substitute for existing public services. In this respect, we can divide public administration electronic services as:

a) public administration electronic services which mediate provision of a specific public service (e.g. request for a meeting with a representative of the self-governing region). These services only add the existing public services provided in the physical world.

b) public administration electronic services whose result of their use is a specific output (e.g. request for a new identity card). These services are adequate replacement of public services provided in the physical world.

c) public administration electronic services provided only online (search for information in public administration information systems or online certificate revocation).

35 More on the issue of identification and authentication see ANDRAŠKO, J. Elektronický občiansky preukaz a iné spôsoby autentifikácie pri prístupe k elektronickým službám verejnej správy, In QUAERE 2017, p. 235-244. 


\section{The definition of public administration electronic services in slovak legal order}

The issue of the eGovernment, especially provision of public administration electronic services is primarily regulated by Act no. 305/2013 Coll. on the Exercise of Public Authorities Competences in Electronic Form and on changes and amendments to certain acts (hereinafter referred to as the "e-Government Act"). The main aim of the e-Government Act is to embody official electronic communication as a primary form of communication between persons (individuals and legal entities) and public authorities as well as between public authorities themselves. ${ }^{36}$

Provisions of e-Government Act apply only to cases when the decision issued is relating to rights, interests protected by law and obligations of natural persons or legal entities. Furthermore, the provisions of e-Government Act are limited to proceedings which result in issuing a decision as an individual legal act. ${ }^{37}$

The e-Government act defines official electronic communication and other institutes necessary for exercise of public authority in electronic form, however the definition of the term public administration electronic services is absent.

The only legal act that is defining the term public administration electronic service is Act no. 275/2006 Coll. on Information Systems of Public Administration (hereinafter as the "ISPA Act”). In accordance with Section 2(1) (s) of the ISPA Act are public administration electronic services defined as "electronic form of communication with liable parties ${ }^{38}$ in the handling of submissions, notifications, access to information and their provision or public participation in the administration of public affairs".

It is necessary to point out that it is clear from the definition of the term public administration electronic services pursuant to the ISPA Act that the term in question does not apply only to decisions relating to rights, interests protected by law and obligations. The term in question defined in the ISPA Act includes submissions, notifications, access to information and their provision as well as public participation in the administration of public affairs. It can be said that in the case of the ISPA Act definition of the term public administration electronic services, there is a wide range of acts that can be done by persons in electronic communication with liable parties.

\section{CONCLUSIONS}

The above analysis of the term public administration electronic services, especially its elements revealed some theoretical issues. It is necessary to point out that public administration electronic services have some common features as well as different features with e-commerce services. Both services are provided by ICT mainly through the Internet. However, the position of the provider and the user is different. In the case of public administration electronic services, public

36 Official electronic communication is defined as electronic communication where the official electronic message which consists of an electronic application and official electronic documents, including attachments, is transmitted.

37 The e-Government Act applies to public authorities. The term public authority (as institution) is broader than the term public administration authorities. More on terminology and structure of public administration authorities see ANDRAŠKO, J. - ŠURKALA, J. The concept of local self-government in the Slovak Republic. In Administrative law and process, 2015, p. 321-332. Available at: http://applaw.knu.ua/2015-2.pdf.

38 The list of liable parties is stated in Section 3 (3) of the ISPA Act. These parties are also known as administrators of information systems of public administration. 
authority that provides specific electronic service is often in monopoly position because the list of public services is limited to only one provider and citizens have no other choice (e.g. welfare services). Furthermore, public administration electronic services are provided by administering public administration entities which provide such services in public interest. In regard to the position of users, they cannot be confused with customers using e-commerce service. In contrast to e-commerce, users of electronic services provided by public authorities are mainly citizens that have a right to use specific public service, while principle of non-discrimination is applied.

One of the categorization of public administration electronic services is emphasizing the importance of public services. In this regard, public administration electronic services are public services that are provided through ICT mainly the Internet. Some of them only mediate the provision of a specific public service in the physical world, while others are a substitute for existing public services. Furthermore, new types of public services accessible only online were created.

Legal definition of the term public administration electronic services stated in the ISPA Act includes a wide range of acts that can be performed by persons in electronic communication with public administration. However, such a definition is not in compliance with the concept of exercise of public authority in electronic form as regulated in the e-Government Act. It would be appropriate to harmonize the terminology regarding to eGovernment and to avoid duplicate definitions that often overlap.

\section{Bibliography:}

ANDRAŠKO, J. Elektronický občiansky preukaz a iné spôsoby autentifikácie pri prístupe k elektronickým službám verejnej správy, In QUAERE 2017, Hradec Králové: Magnanimitas, 2017, p. 235-244.

ANDRAŠKO, J. - ŠURKALA, J. The concept of local self-government in the Slovak Republic. In Administrative law and process, 2015, Vol. 12, Issue 2, p. 321-332. Available at: http://applaw.knu.ua/2015-2.pdf.

BOYER, K. et al. Eservices: operating strategy-a case study and a method for analyzing operational benefits. In Journal of Operations Management, 2002, Vol., no. 2. p. 175-185.

HEEKS, Richard: Implementing and Managing eGovernment: an International Text. London: Sage, 2006, 293 p.

HOFACKER, Ch. F. et al. E-Services: A Synthesis and Research Agenda. In Journal of Value Chain Management, 2007, Vol. 1, no. 1, p. 13-44.

CHAIKHI, L- et al. E-Government Maturity Models: A Comparative Studies. In International Journal of Software Engineering \& Applications, 2014, Vol. 15, no. 3, p. 71-91.

JAVALGI, R. G. et al. The Export of E-Services in the Age of Technology Transformation: Challenges and Implications for International Service Providers. In Journal of Services Marketing, 2004, Vol. 18, no. 7, p. 560-573.

LAYNE, K. - LEE, J. Developing fully functional E-government: A four stage model. In Government Information Quarterly, 2001, Vol. 18 no. 2, p. 122-136.

LINDGREN, I. - JANSSON, G. Electronic services in the public sector: A conceptual framework. In Government Information Quarterly, 2013, Vol. 30, no. 2, p. 163-172.

OCHRANA, F. Veřejné služby - problém vymezení pojmu a standardizace. In Standardizace veřejných služeb jako předpoklad efektivnosti rozvoje regionů. Brno: Masarykova univerzita, ESF, 2003, p. 16-21.

PARASURAMAN, A. et al. A Conceptual Model of Service Quality and Its Implications for Future Research. In Journal of Marketing, 1985, Vol. 49, no. 4, p. 41-50.

PEKOVÁ, J. et al. Veřejný sektor - řízení a financování. Praha: Wolters Kluwer ČR, 2012, 488 p.

ČEBIŠOVÁ, T. Veřejná služba na prahu 21. století. In Acta Universitas Carolinae, 2001, Vol. no. 1-2, p. 9-39.

POMAHAČ, R. - VIDLÁKOVÁ, O. Veřejná správa. Praha: C. H. Beck, 2002, 290 p. 
VRABKO, M. et al. Správne právo hmotné. Všeobecná čast'. Bratislava: C. H. Beck, 2012, 480 p.

PRINS, J.E.J.: E-Government and Its Implications for Administrative Law:Regulatory Initiatives in France, Germany, Norway and the United States. Hague: T.M. Asser Press, 2002, 225 p.

KOTLER, P. - KELLER, K. L. Marketing Management. London: Pearson Education Ltd., 2013, 814 p.

SAUTER, W. Public Services in EU Law. Cambridge: Cambridge University Press, 2015, 262 p.

SCUPOLA, A. et al. E-Services: Characteristics, Scope and Conceptual Strengths. In International Journal of EServices and Mobile Applications, 2009, Vol. 1, no. 3, p. 1-16.

SILCOCK, R. What is e-government? In Parliamentary Affairs, 2001, Vol. 54, no. 1, p. 88-101.

SOPÚCHOVÁ, S. Predpoklady fungovania e-governmentu v Slovenskej republike In QUAERE 2015. Hradec Králové : Magnanimitas, 2015. p. 659-668.

SKULOVÁ, S. Princípy dobré správy jako součást modernizace veřejné správy. In Právnik, 2005, Vol. CXLIV, no. 6, p. 553-585.

ŠPAČEK, D. eGovernment - cíle, trendy a přístupy k jeho hodnocení. Praha: C. H. Beck, 2012, 258 p.

ZOURIDIS, S. - THAENS, M. E-Government: Towards a Public Administration Approach. In Asian Jopurnal of Public Administration, 2003, Vol. 25, no. 2, p. 159-183.

MINISTERSTVO FINANCIÍ SLOVENSKEJ REPUBLIKY: Metodický pokyn na použitie odborných výrazov pre oblast' informatizácie spoločnosti. Bratislava, 2008.

Act no. 305/2013 Coll. on the Exercise of Public Authorities Competences in Electronic Form and on changes and amendments to certain acts

Act no. 275/2006 Coll. on Information Systems of Public Administration

OSN. World Public Sector Report 2003. E-Government at the crossroads. New York. 2003, 242 p. Available at: https://publicadministration.un.org/publications/content/PDFs/E-Library\%20Archives/World\%20Public\%20 Sector\%20Report\%20series/World\%20Public\%20Sector\%20Report.2003.pdf

\section{Contact information:}

JUDr. Jozef Andraško, PhD.

jozef.andrasko@flaw.uniba.sk

Comenius University in Bratislava, Faculty of Law

Šafárikovo nám. č. 6

P. O. BOX 313

81000 Bratislava

Slovak Republic 